\title{
ECOLOGICAL AND MOLECULAR APPROACH TO THE ASSESSMENT OF OIL POLLUTION: A COMPARATIVE STUDY BETWEEN TWO COASTAL MARINE (MEDITERRANEAN AND PATAGONIAN) ECOREGIONS
}

\author{
GIUSEPPE ZAPPALÀ ${ }^{1}$, GABRIELLA CARUSO ${ }^{2}$, RENATA DENARO ${ }^{3}$, \\ FRANCESCA CRISAFI $^{1} \&$ LUIS SALVADOR MONTICELLI ${ }^{4}$ \\ ${ }^{1}$ National Research Council, Institute of Biological Resources and Marine Biotechnologies (CNR-IRBIM), Italy \\ ${ }^{2}$ National Research Council, Institute of Polar Sciences (CNR-ISP), Italy \\ ${ }^{3}$ National Research Council, Water Research Institute (CNR-IRSA), Italy \\ ${ }^{4}$ National Research Council, Institute for Coastal Marine Environment (CNR-IAMC), Italy
}

\begin{abstract}
Microorganisms are considered as sentinels of environmental changes, but microbial response to the presence of contaminants, such as hydrocarbons, is still not fully understood. This study aimed at assessing the response of the microbial community to the presence of oil pollution, by comparison of two ecosystems, Milazzo Gulf (Sicily, Italy) and Caleta Cordova (Argentina), as representative of two different temperate Mediterranean and cold-temperate Patagonian ecoregions, respectively. Water and sediments were sampled at coastal stations characterized by different levels of hydrocarbon contamination and analyzed for their microbial enzymatic activity rates; the presence of hydrocarbondegrading bacteria was also determined. The study approach allowed to determine that microbial metabolism was significantly reduced at the polluted stations, suggesting the detrimental effects of contaminants on organic matter degradation process. The isolation of strains of hydrocarbon-degrading bacteria confirmed that the oil contamination favoured the growth of strains specifically adapted to metabolize hydrocarbons and actively involved in the remediation processes.
\end{abstract}

Keywords: oil pollution, microbial response, enzyme activities, hydrocarbon-degrading bacteria.

\section{INTRODUCTION}

Oil pollution is a major threat for world's oceans and a severe cause of environmental deterioration [1], [2]; petroleum hydrocarbons can enter into aquatic environments as a consequence of natural oil sources following freshwater runoff, rivers and sewage systems [3], [4] or as a result of human activities related to oil extraction and refinery, causing chronic pollution (i.e. maritime transports or shipping activities) or following occasional oil spill events caused by pipeline failures or shipping disasters (i.e. Exxon Valdez, Deepwater Horizon) that generally result in acute pollution.

In order to optimize decision making response to oil spills, a deep knowledge of the fate of oil spill and ecological effects related to hydrocarbon compounds discharged into the environment is necessary. In temperate regions, an early weathering phase of oil spills leads to its evaporation, absorption in water and dispersion [5]. Following hydrodynamic forcings such as currents and waves, emulsification and dispersion of spilled oil starts, making its components available as a carbon source to a fraction of indigenous microbiological populations able to metabolize them [1], [6], [7]. Hydrocarbon-degrading bacteria are autochthonous microorganisms widespread in the marine environment, able to use hydrocarbons as the sole carbon source and therefore extremely specialized in the removal of these contaminants [1], [8]. Due to their persistence and accumulation along the trophic web, the toxic effects of hydrocarbon contamination on marine biota, such as benthic communities are well known [2], [9]. Knowledge of the effects of oil pollution on the microbial community structure and function is comparatively low. 
Microorganisms are considered as sentinels of environmental changes; indeed, they are able to respond to the presence of contaminants by modifying their abundance and/or metabolism [10]. Heterotrophic bacteria, which play a major role in the particulate to dissolved matter transformation, are known to promptly respond to environmental changes, modifying their metabolic patterns according to available organic compounds. Thanks to their metabolic activities on organic polymers (proteins, organic phosphates), marine microorganisms make the nutrients $(\mathrm{N}, \mathrm{P})$ necessary for the development of hydrocarbon bacteria available in inorganic form. The addition of nutrients is in fact a strategy used to stimulate the bioremediation process, as the in situ microbial degradation of contaminants is generally slow due to the low availability of nutrients and oxygen. Therefore, the estimate of the decomposition rates of organic matter can provide useful information on the flux of elements made available by the microbial activity of enzymatic hydrolysis; this can be a biostimulating factor towards hydrocarbon bacteria. In situ characterization of metabolic potential is therefore essential to assess the potential ability of microbial assemblage to be involved in decomposition processes. Indeed, microbial enzymatic activities can constitute potential bio-indicators of the microbial degradation capacity on hydrocarbons and an alternative approach to monitor the progress of the processes of bioremediation [3].

The rationale of this study was to investigate the in situ potential of autochthonous hydrocarbon-degrading bacteria during the natural occurring clean-up processes in two cold and temperate environments which are at risk of oil pollution, Caleta Cordova because of the oil-based industrial activity, Milazzo Gulf due to the presence of a refinery plant and intensive maritime traffic within its harbor. To this aim, within the joint Cooperation Agreement between Italy and Argentina funded by CNR, a study was undertaken on the pelagic and benthic compartments in order to assess the response of the microbial community to the presence of oil pollution, by comparison of two ecosystems, Milazzo Gulf and Caleta Cordova, as representative of temperate Italian and cold-temperate Patagonian ecoregions, respectively.

The specific objectives of this study were: (i) to assess the microbial extracellular enzymatic activity of the microbial assemblage in the water and sediments of coastal marine sites differently impacted by oil pollution; and (ii) to isolate hydrocarbon-degrading bacteria from the sediments. The study approach allowed to determine the expression of microbial activities related to organic matter turnover and metabolic functioning simultaneously to the characterization of the microbial assemblage specifically involved in bioremediation process.

\section{MATERIALS AND METHODS}

\subsection{Study sites and sampling}

Samplings of water and sediments were performed at Mediterranean (Milazzo Gulf) and Patagonian (Caleta Cordova) coastal marine stations. The location of the study areas with indication of the sampling stations is shown in Fig. 1.

\subsubsection{Italian site}

The Gulf of Milazzo ecosystem (Fig. 1(a)) is located in the Tyrrhenian Sea, along the northeastern coast of Sicily; in its western part it receives organic matter inputs coming from stream and urban and industrial settlements. A study by Yakimov et al. [11] reported concentrations of alkanes (C12-C16 atoms) and alkyl phthalates of 143 and $61 \mu \mathrm{g} / \mathrm{kg}$ per dry weight of sediment, respectively. Unlike the hydrological and general biological parameters, 


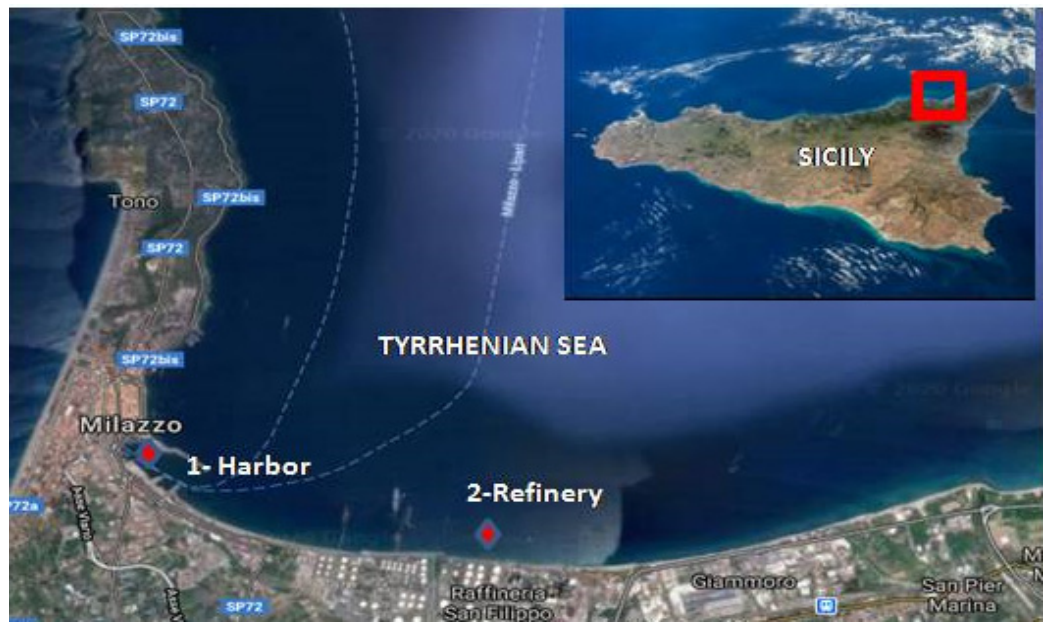

(a)

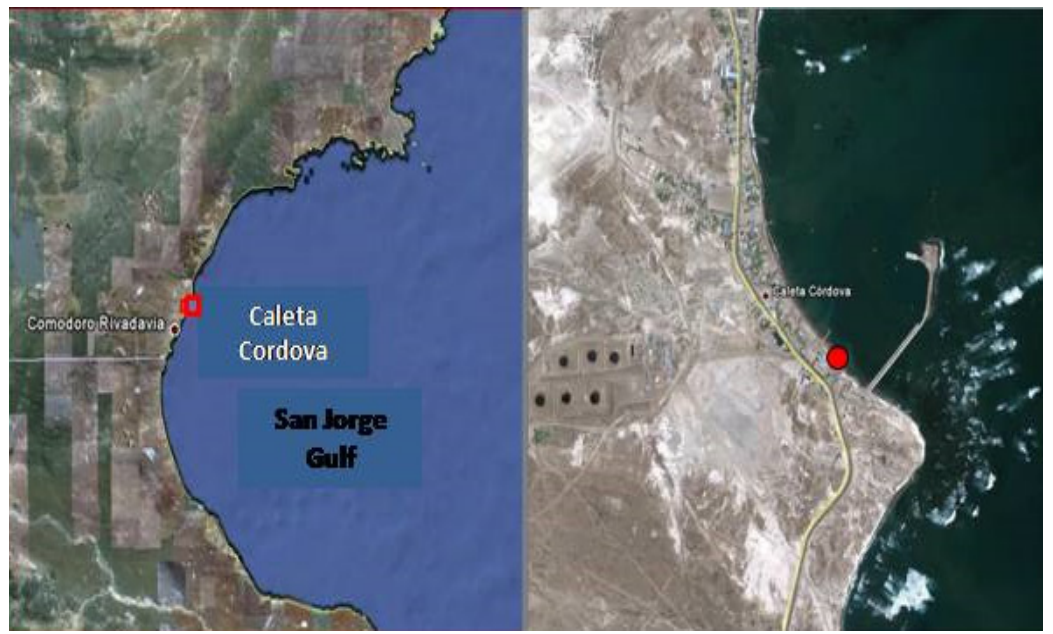

(b)

Figure 1: Location of the study areas. (a) Milazzo Gulf as a temperate Mediterranean site; and (b) Caleta Cordova as a sub-Antarctic Patagonian site. The sampling sites are indicated by the red symbols.

bacterial dynamics and metabolism in this ecosystem remain poorly understood. On 3 December 2009, two stations - one located within the Milazzo harbor and one in front of the Milazzo refinery - were sampled.

\subsubsection{Patagonian site}

Sampling in Patagonia was performed on 8 June 2010, in a seasonal period (late autumnwinter) comparable with that in which the activities were carried out in Italy. The sampled site was Caleta Córdova (Province: Chubut) located on the San Jorge Gulf, within the Comodoro Rivadavia oil basin. The chosen area represents one of the centres of the Argentine 
oil industry characterized by the presence of numerous augers near the coast. In coastal sediments, total aliphatic and aromatic hydrocarbons reached concentrations of 106.3 and $107.8 \mu \mathrm{g} / \mathrm{g}$ per dry weight of sediment, respectively [12]. Two stations $100 \mathrm{~m}$ far from each other - indicated as CC10(1) and CC10(2) - were sampled. Sediment sampling was carried out using plexiglass pipes with sharp edges, collecting portions of sediment while remaining within a circle of about $1 \mathrm{~m}^{2}$.

\subsection{Measured variables}

At the time of sampling, in situ measurements of temperature, $\mathrm{pH}$ and oxidation-reduction potential Eh were carried out. The following microbial parameters were measured: extracellular enzymatic activities (EEA: leucine aminopeptidase, LAP and alkaline phosphatase, AP) and heterotrophic bacterial abundance (MA) by Marine Agar plate counts. EEA were determined using the specific fluorogenic substrates L-leucine-7-amido-4-methylcoumarin hydrochloride (LEU-MCA), 4-methylumbelliferyl (MUF)-phosphate for LAP and AP) and reported in terms of the maximum velocity of hydrolysis $\left(\mathrm{V}_{\max }\right)[3]$.

\subsection{Hydrocarbon-degrading bacteria isolation}

On the same day of sampling, the collected seawater and sediments samples were mixed to make them homogeneous and distributed among the researchers according to the needs of the planned analyses. Microcosms were set up in order to enrich the relative densities of hydrocarbon-degrading bacteria formed by the natural sample slurry, amended with nutrients-containing ONR7a medium and hydrocarbons as sole source of carbon. Samples collected at Caleta Córdova (austral winter season) were incubated at $4{ }^{\circ} \mathrm{C}$ according to the in situ measured temperature (Table 1) for approximately 5 weeks. For the samples collected in the Gulf of Milazzo incubation lasted 15 days. The microcosms prepared in 1/1 ratio with ONR $7 \mathrm{a}$ were added with the substrate $(0.1 \%$ tetradecane or $0.1 \%$ Phenanthrene). The microcosms were prepared in triplicate for each site: the first set was designed for bacterial isolation and kept at $4^{\circ} \mathrm{C}$, the second one was kept at $15^{\circ} \mathrm{C}$, the third one - that was immediately treated with hydrochloric acid and stored at $4^{\circ} \mathrm{C}$ - was used for the chemical analyses.

\subsection{Phylogenetic analyses}

Analyses of the 16S rDNA gene sequences of isolates were performed as previously described [13]. Briefly, DNA extraction of bacterial isolates was performed with the CTAB method [14]. 16S rDNA loci were amplified using 16S rDNA forward domain-specific bacteria, Bac27_F (5'-AGAGTTTGATCCTGGCTCAG-3') and reverse primer Uni_1492R (5'-TACGYTACCTTGTTACGACTT-3') [15]. The amplification reaction was performed in a total volume of $50 \mu \mathrm{l}$ mixture containing solution Q (Qiagen, Hilden, Germany), Qiagen reaction buffer, $1 \mu \mathrm{M}$ of each forward and reverse primer, $10 \mu \mathrm{M}$ dNTPs (Gibco, Invitrogen Co., Carlsbad, CA, USA), $2.0 \mu \mathrm{M}(50-100 \mathrm{ng})$ of template and 2.0 U of Qiagen Taq Polymerase (Qiagen). The amplified 16S rDNA was sequenced using Macrogen Service (Korea). SIMILARITY_RANK from the Ribosomal Database Project (RDP) [16] and FASTA Nucleotide Database Query were used to determine partial 16S rDNA sequences to estimate the degree of similarity to other $16 \mathrm{~S}$ rDNA gene sequences. Analysis and phylogenetic affiliates of sequences was performed as previously described [17]. 


\subsection{Chemical analyses}

The selection of hydrocarbon-degrading bacteria was carried by estimation of degradation efficiency within microcosms according to Crisafi et al. [13] by the analysis of total extracted and resolved hydrocarbons (TERHC). Briefly: at the fixed time points, TERCH were extracted from water sample following the 3510C EPA procedure (US Environmental Protection Agency). $500 \mathrm{ml}$ of seawater were added with a mixture of acetonedichloromethane 1:1 ( $\mathrm{vol} / \mathrm{vol})$ and shaken at $150 \mathrm{rpm}$ for $30 \mathrm{~min}$; the extract was treated with anhydrous $\mathrm{Na}_{2} \mathrm{SO}_{4}$ (Sigma-Aldrich, Milan, Italy). The same treatment was repeated twice with $500 \mathrm{ml}$ of dichloromethane. After drying, residues were re-suspended in $1 \mathrm{ml}$ of dichloromethane and analyzed by gas chromatography [18] according to Crisafi et al. [13]. Data obtained were normalized by decamethylanthracene (internal spike/control of biodegradation) and used to evaluate the relative biodegradation of hydrocarbon.

\section{RESULTS}

\subsection{Physical-chemical variables}

\subsubsection{Milazzo Gulf}

The values of the physical and chemical variables measured in Milazzo Gulf are shown in Table 1. Temperature showed higher values at the refinery station compared to the harbor station. $\mathrm{pH}$ and $\mathrm{Eh}$ were in a range similar to other temperate marine environments.

Table 1: Milazzo Gulf: Physical-chemical variables measured at the sampling sites.

\begin{tabular}{|l|c|c|c|}
\hline \multirow{2}{*}{ Site } & \multicolumn{3}{|c|}{ Milazzo Gulf } \\
\cline { 2 - 4 } & Temperature & $\mathrm{pH}$ & Eh \\
\hline 1. Harbor & 17.21 & 7.8 & 144 \\
\hline 2. Refinery & 18.32 & 7.6 & 168 \\
\hline
\end{tabular}

\subsubsection{Caleta Cordova}

Physical-chemical measurements performed at Caleta Cordova gave the dataset reported in Table 2. Temperature values were typical of a cold sub-Antarctic region and did not differ significantly between the two stations; $\mathrm{pH}$ and Eh ranges also did not show evident differences. Despite the proximity to the extraction plants, no evident signs of a contamination from oil or hydrocarbons were observed, either due to halos on the water surface or to residues on the beach. Some patches of the collected sediment samples showed parts of dark sand, probably due to anaerobic zones rather than to the presence of hydrocarbons.

\subsection{Enzyme activity rates}

In both the examined sites, LAP predominated compared to AP, suggesting a higher amount of degradable organic polymers with a proteinaceous nature with respect to organic phosphates.

In the waters of Milazzo (Fig. 2), LAP activity rates ranged from 4.68 to $6.63 \mathrm{nmol} / \mathrm{l} / \mathrm{h}$, while AP showed activity rates comprised between 3.85 and $18.17 \mathrm{nmol} / \mathrm{l} / \mathrm{h}$.

In the sediments of Milazzo (Fig. 3), higher enzymatic levels were measured, ranging from 9.10 to $32.33 \mathrm{nmol} / \mathrm{g} / \mathrm{h}$ and from 6.81 to $21.18 \mathrm{nmol} / \mathrm{g} / \mathrm{h}$ for LAP and AP respectively. 
Table 2: Caleta Cordova: Physical-chemical variables measured at three points per each site.

\begin{tabular}{|c|c|c|c|c|}
\hline Sampling site & Triplicated points & Temperature & $\mathrm{pH}$ & Eh \\
\hline \multirow{4}{*}{$\begin{array}{l}\text { Caleta Cordova } 1 \\
45^{\circ} 45.135^{\prime} \mathrm{S} \\
67^{\circ} 22.341^{\prime} \mathrm{W} \\
\text { Mean } \pm \text { s.d. }\end{array}$} & $1 \mathrm{a}$ & 2.9 & 7.4 & 158 \\
\hline & $1 \mathrm{~b}$ & 3.1 & 8.0 & 165 \\
\hline & $1 \mathrm{c}$ & 3.3 & 7.9 & 163 \\
\hline & & $3.1 \pm 0.2$ & $7.8 \pm 0.3$ & $162 \pm 4$ \\
\hline \multirow{4}{*}{$\begin{array}{l}\text { Caleta Cordova } 2 \\
45^{\circ} 44.911^{\prime} \mathrm{S} \\
67^{\circ} 22.597^{\prime} \mathrm{W} \\
\text { Mean } \pm \text { s.d. }\end{array}$} & $2 \mathrm{a}$ & 3.1 & 7.9 & 140 \\
\hline & $2 b$ & 3.6 & 8.0 & 146 \\
\hline & $2 \mathrm{c}$ & 3.7 & 7.9 & 170 \\
\hline & & $3.3 \pm 0.3$ & $7.9 \pm 0.1$ & $152 \pm 16$ \\
\hline
\end{tabular}
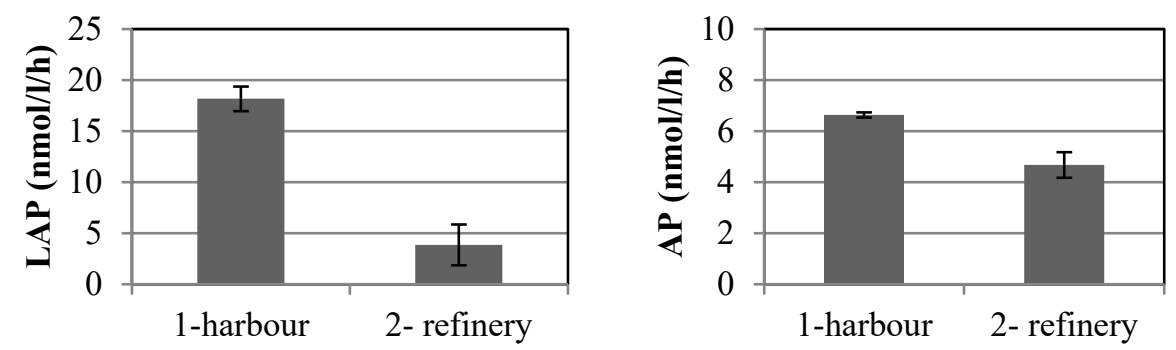

Figure 2: Mean \pm s.d. enzyme activity rates measured in the Milazzo Gulf water.
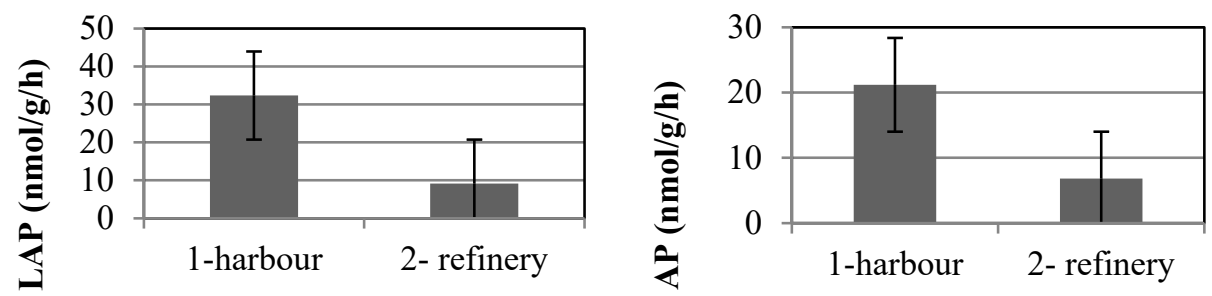

Figure 3: Mean \pm s.d. enzyme activity rates measured in the Milazzo Gulf sediments.

Higher metabolic activity levels were always recorded inside the Milazzo harbor, while in front of the refinery the metabolism of the microbial community inhabiting both pelagic and benthic compartments appeared to be significantly $(\mathrm{P}<0.01)$ reduced.

In Caleta Cordova LAP values ranged from 2 to $15 \mathrm{nmol} / \mathrm{l} / \mathrm{h}$ and from 901.81 to $1568.66 \mathrm{nmol} / \mathrm{g} / \mathrm{h}$ in water and sediments (Figs 4 and 5), respectively. In the same compartments, AP values were comprised between 0.21 to $1.49 \mathrm{nmol} / \mathrm{l} / \mathrm{h}$ and between 56 and $141.3 \mathrm{nmol} / \mathrm{g} / \mathrm{h}$, respectively. The spatial distribution patterns of both LAP and AP enzymatic values showed a greater metabolic activity of the microbial community at station 2 both at the water and sediment level. 

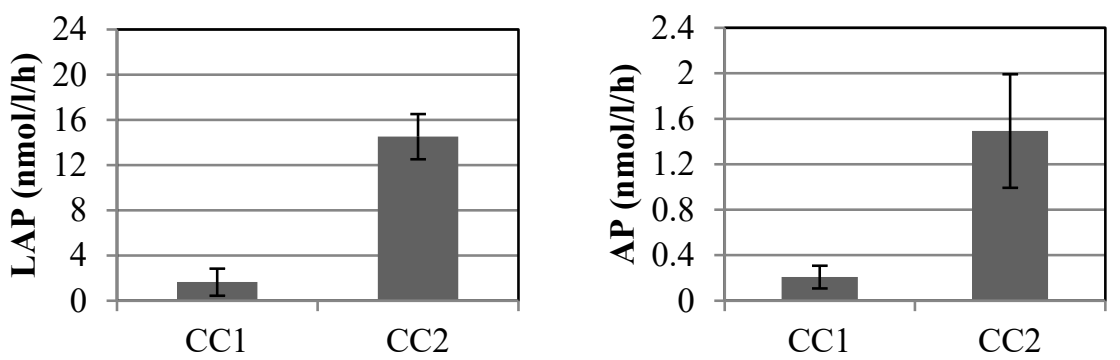

Figure 4: Mean \pm s.d. enzyme activity rates measured in the Caleta Cordova water.
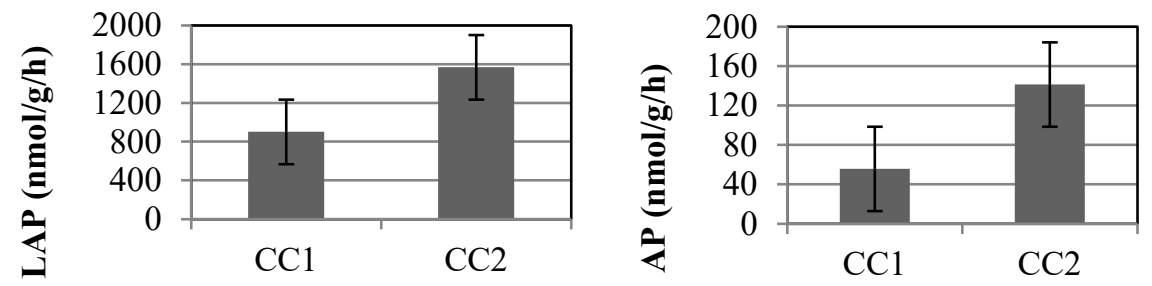

Figure 5: Mean \pm s.d. enzyme activity rates measured in the Caleta Cordova sediments.

\subsection{Hydrocarbon-degrading bacteria}

After 8 days of incubation at the established temperatures, $100 \mu$ laliquots of the slurry collected from microcosms were used for serial dilutions up to a dilution factor of $10^{-4}$. $100 \mu \mathrm{l}$ of each dilution were inoculated in ONR7a amended with previously used hydrocarbons, namely $0.1 \%$ tetradecane or $0.1 \%$ phenanthrene $(\mathrm{w} / \mathrm{v})$ collected from Caleta Cordova and maintained at $4{ }^{\circ} \mathrm{C}$, while samples collected from Milazzo Gulf were maintained at $15^{\circ} \mathrm{C}$. When an increase in turbidity was observed in the cultures, aliquots of $100 \mu 1$ were inoculated in ONR7a solid medium. As soon as the different morphologies of colonies were distinguishable, 10 strains from Caleta Cordova samples and 23 strains from Milazzo Gulf were selected for further isolation step and then phylogenetic analyses.

Results of the isolation of bacterial strains are reported in Tables 3 and 4 for Milazzo Gulf and Caleta Cordova, respectively. Bacterial strains isolated from Milazzo Gulf showed in general a higher degradation performance, also due to the higher experimental temperature. All the strains grown in tetradecane already after 20 days showed a decrease of the pollutant in the range of 50-60\%. A peculiar behavior was observed in Alcanivorax dieselolei B5, a hydrocarbonoclastic bacterium well-known for the capability to degrade oil, also by the production of biosurfactants [19]. The strain isolated from Milazzo Gulf showed the highest performance, degrading in 20 days the $80 \%$ of tetradecane. Strains belonging to Marinobacter and Halomonas genera degraded the $60 \%$ of the pollutant. The cultures supplemented with phenanthrene were maintained for 30 days, obtaining a $25 \%$ decrease of the total amount of the pollutant in presence of Pseudomonas, and lower percentages (15$20 \%$ ) in presence of Rhodococcus and Vibrio. 
Table 3: Milazzo Gulf: Number of bacterial isolates obtained on media containing tetradecane and phenantrene as substrates.

\begin{tabular}{|c|l|c|c|c|}
\hline $\begin{array}{c}\text { Number of } \\
\text { isolates }\end{array}$ & Closest match to & $\mathbf{\%}$ & Accession number & Substrate \\
\hline 7 & Alcanivorax dieselolei B5 & 98 & NR 074734 & Tetradecane \\
\hline 5 & Marinobacter sp. PJ-24 & 99 & KC200265 & Tetradecane \\
\hline 3 & Halomonas venusta & 98 & KJ416384 & Tetradecane \\
\hline 3 & Rhodococcus yunnanensis & 97 & JX827199 & Phenantrene \\
\hline 4 & Pseudomonas sp. PAHAs-1 & 97 & KF483151 & Phenantrene \\
\hline
\end{tabular}

Table 4: Caleta Cordova: number of bacterial isolates obtained on media containing tetradecane and phenantrene as substrates.

\begin{tabular}{|c|l|c|c|c|}
\hline $\begin{array}{c}\text { Number of } \\
\text { isolates }\end{array}$ & Closest match to & $\mathbf{\%}$ & $\begin{array}{c}\text { Accession } \\
\text { number }\end{array}$ & Substrate \\
\hline 4 & Marinobacter antarcticus & 98 & NR_108299 & Tetradecane \\
\hline 3 & Oleispira antarctica & 99 & NR_025522 & Tetradecane \\
\hline 1 & Rhodococcus sp. ice-oil-488 s & 98 & DQ521396 & Tetradecane \\
\hline 2 & Sphingopyxis flavimaris & 99 & NR 025814 & Phenantrene \\
\hline 4 & Pseudoalteromonas arctica & 98 & HG795046 & Phenantrene \\
\hline
\end{tabular}

Bacterial strains isolated from Caleta Cordova were affiliated to genera already described as hydrocarbon-degrading. In particular, the isolates were referable to species adapted to cold, sub-Antarctic, environments. Marinobacter antarcticus showed cream-colored colonies, $1.5 \mathrm{~mm}$ diameter, halotolerant (optimum 3.0-4.0\% $\mathrm{NaCl} \mathrm{w} / \mathrm{v}$ ). The capability to degrade hydrocarbons was calculated as percentage of decrease in the amount of tetradecane compared to the un-inoculated control. The $30 \%$ of the added pollutant was degraded after 30 days. Oleispira antarctica is the first hydrocarbonoclastic bacterium identified in Antarctica [20], it grows with circular and cream-yellow colored colonies. After 30 days incubation, $40 \%$ of tetradecane was degraded. Rhodococcus was frequently described as hydrocarbon-degrading in single culture but also in consortia where it seems to improve the action of specialists hydrocarbonoclastic bacteria. Indeed, isolates belonging to Rhodococcus genus were less performant; after 30 days only about $15 \%$ of tetradecane was degraded. The degradation of phenanthrene at $4^{\circ} \mathrm{C}$ was assayed after 45 days of incubation. Both isolated strains showed a low growth performance and consequently also the degradation of the pollutant did not reach more than $5 \%$ of degradation.

\section{DISCUSSION}

Coastal marine environments are the most vulnerable regions to anthropic pressure, requiring advanced technologies for their proper knowledge and monitoring [21], [22]. Since the recent increase of oil spills (i.e. Exxon Valdez, Deep Horizon etc.), several studies have started to investigate the effects on marine biota, also including microbes, related to the presence of hydrocarbon contaminants [2], [10], [23], [24]. It is well known that a disturbance can modify microbial community composition [25] and, in turn, structural changes result in functional changes. To this regard, a reduction in microbial diversity was reported to affect general metabolic activity as well as the functional ability of the microbial community to degrade pollutants [26]. Our study addressed the response to oil contamination of the microbial community present in water and sediments, taking into account both microbial metabolism - 
by extracellular enzyme activity measurements - and composition - by isolation of oildegrading bacteria.

Microbes are recognized to play a key role in bioremediation processes; therefore, it is extremely important to study the relationships between microbial community structure and metabolic activity as a key step to elucidate how the microbial assemblage responds to oil pollution. On the other hand, the metabolic potential of oil-degrading communities by itself depends on the structure and diversity of microbial assemblage [8]. One possible limitation when assessing the ecological consequences of oil pollution is related to the fact that most of the studies of hydrocarbon-degrading microorganisms refer to laboratory experiments, involving the cultivation of bacteria; this makes understanding and prediction of in situ dynamics of microbial communities in response to oil discharge quite difficult [27] and explain the importance of combining culture with direct methods such as the biochemical ones to achieve a better comprehension of microbial dynamics.

\subsection{Microbial metabolism}

In both the study sites, LAP was the prevalent enzyme; proteolytic activity is widespread in the microbial community of temperate environments. The bacterial activity values measured in Milazzo Gulf ranged in the same order of magnitude as those reported for other pelagic Mediterranean waters. The obtained enzymatic data suggested that microbial metabolism was significantly depressed at the polluted stations, pointing out the negative effects of contaminants on organic matter degradation process. Similar findings were reported by a previous study [28], where oil pollution was reported to alter the structure and function of the whole microbial community. In this sense, functional diversity has been indicated as a key factor to assess the recovery of the microbial community after oil spill [29]. Nevertheless, controversial results on the effects of hydrocarbons on microbial metabolism are available in the scientific literature. In contrast with our results, Ziervogel et al. [30] detected, until 3 months after the Deepwater Horizon disaster, enhanced lipase activity and bacterial protein production in the surface $(0-2 \mathrm{~cm})$ sediment layers at the sites close to oil contamination, while leucine-aminopeptidase activity was depressed; this result indicated the stimulation of benthic microbial enzymatic hydrolysis of oil-derived organic matter that contained no proteins. A similar observation was reported by Ziervogel et al. [31] in a 21-day laboratory experiment in roller bottles to simulate microbial dynamics occurring in oil-contaminated waters; these Authors found bacterial-colonized oil aggregates, characterized by high lipase, LAP and glucosidase activities, although these last two enzymes are not directly related to primary oil-degradation. In deltaic lagoon sediments affected by persistent organic pollutants, Zoppini et al. [32] found increased prokaryotic production, enzymatic and community respiratory activities, pointing out the contribution of the benthic microbial community to sediment self-purification processes. Again, higher bacterial extracellular enzyme activities (lipase, $\alpha$ - and $\beta$-glucosidase, alkaline phosphatase, leucine aminopeptidase) and micro-aggregate counts were observed by Kamalanathan et al. [33] in a mesocosm study where tanks feed with Mexico Gulf water contaminated after the Deepwater Horizon oil spill, and added with chemical dispersants, were compared to controls without supplementation.

In the sediments of Milazzo and Caleta Cordova, enzyme activity rates up to 1-2 orders of magnitude higher than those recorded in the pelagic compartment were measured in our study, highlighting the role of benthic compartment as environmental archives and reservoirs of contaminants that can sink and accumulate within the sedimentary matrix. 


\subsection{Hydrocarbon-degrading bacteria}

The isolation of bacterial hydrocarbon-degrading strains confirmed that the marine sites under study, known to have experienced oil contamination in the past, have a great potential in the response to oil-pollution. The growth of strains specifically adapted to use hydrocarbons and actively involved in the remediation processes let us hypothesize that they play a crucial role in the natural occurring clean-up processes also envisaging a biotechnological perspective for in situ bioremediation treatments. The results demonstrate the potential of both sites and evidence their peculiarities, with special attention to the temperature as one of the limiting factors for the success of bioremediation in marine environments.

In conclusion, in our study, both microbial structure and function in water and sediments appeared to be significantly affected by oil pollution. In order to minimize the environmental impact of oil spills and optimize the effectiveness of biodegradation measures, further estimates of the in situ metabolic potential of hydrocarbon-degrading bacteria and of the factors that limit microbially-catalyzed biodegradation will be needed.

Through long-term monitoring of polluted environments and the definition of baseline values related to the metabolic activity of the microbial community, it will be possible to assess the recovery of marine ecosystems after contamination.

\section{ACKNOWLEDGEMENTS}

This study was funded by the bilateral CNR and CONICET international cooperation research program "Global biodegradation network: ecological and molecular approach in the assessment of the oil pollution in the marine environment. A comparative and integrative study applied in two different coastal marine ecoregions (Mediterranean and Patagonian shelf)" (2009-2010). Particular thanks are due to Dr H. Dionisi (Laboratorio de Microbiología Ambiental, Centro para el Estudio de Sistemas Marinos, Centro Nacional Patagonico, CENPAT-CONICET, Puerto Madryn, Argentina), who supported the research activities in Patagonia.

\section{REFERENCES}

[1] Yakimov, M.M., Timmis, K.N. \& Golyshin, P.N., Obligate oil-degrading marine bacteria. Current Opinions in Biotechnology, 18(3), pp. 257-266, 2007.

[2] Sadooun, I.M.K., Impact of oil spills on marine life. Emerging Pollutants in the Environment - Current and Further Implications, eds M.L. Larramendy \& S. Soloneski, IntechOpen: London, Chapter 4, 2015.

[3] Cappello, S. et al., Microbial community dynamics during assays of harbour oil spill bioremediation: A microscale simulation study. Journal of Applied Microbiology, 102(1), pp. 184-194, 2007.

[4] Hassanshiahian, M., Emtiazi, G., Caruso G. \& Cappello, S., Bioremediation (bioaugmentation/biostimulation) trials of oil polluted seawater: A mesocosm simulation study. Marine Environmental Research, 95, pp. 28-38, 2014.

[5] ITOPF.org, Environmental effects, 2016. www.itopf.com/knowledge-resources/ documents-guides/environmental-effects/. Accessed on: 6 Aug. 2020.

[6] Atlas, R.M. \& Cerniglia, C.E., Bioremediation of petroleum pollutants. Bioscience, 45(5), pp. 1-10, 1995.

[7] Hazen, T.C., Prince, R.C. \& Mahmoudi, N., Marine oil biodegradation. Environmental Science and Technology, 50(5), pp. 2121-2129, 2016. 
[8] Head, I.M., Jones, D.M. \& Röling, W.F., Marine microorganisms make a meal of oil. Nature Reviews Microbiology, 4(3), pp. 173-182, 2006.

[9] Howarth, R.W., Determining the ecological effects of oil pollution in marine ecosystems. Ecotoxicology: Problems and Approaches. Springer Advanced Text in Life Sciences, eds S.A. Levin, J.R. Kelly, M.A. Harwell \& K.D. Kimball, Springer: New York, pp. 69-97, 1989.

[10] Nogales, B., Lanfranconi, M.P., Piña-Villalonga, J.M. \& Bosch, R., Anthropogenic perturbations in marine microbial communities. FEMS Microbiological Reviews, 35, pp. 275-298, 2011. DOI: 10.1111/j.1574-6976.2010.00248.x.

[11] Yakimov, M. et al., Natural microbial diversity in superficial sediments of Milazzo Harbor (Sicily) and community successions during microcosm enrichment with various hydrocarbons. Environmental Microbiology, 7(9), pp. 1426-1441, 2005.

[12] Commendatore, M.G. \& Esteves, J.L., An assessment of oil pollution in the coastal zone of Patagonia, Argentina. Environmental Management, 40, pp. 814-821, 2007.

[13] Crisafi, F., Giuliano, L., Yakimov, M.M., Azzaro, M. \& Denaro, R., Isolation and degradation potential of a cold-adapted oil/PAH-degrading marine bacterial consortium from Kongsfjorden (Arctic region). Rendiconti Lincei, 27(1), pp. 261-270, 2016.

[14] Winnepenninckx, B., Backeljau, T. \& De Wachter, R., Extraction of high molecular weight DNA from molluscs. Trends in Genetics, 9(12), p. 407, 1993.

[15] Lane, D.J., 16/23S rRNA sequencing. Nucleic Acid Techniques in Bacterial Systematics, eds E. Stackebrandt \& M. Goodfellow, John Wiley: New York, pp. 115$175,1991$.

[16] Maidak, B.L., Olsen, G.J., Larsen, N., Overbeek, R., McCaughey, M.J. \& Woese, C.R., The RDP (ribosomal database project). Nucleic Acids Research, 25(1), pp. 109-111, 1997.

[17] Yakimov, M.M. et al., Phylogenetic survey of metabolically active microbial communities associated with the deep-sea coral Lophelia pertusa from the Apulian Plateau, Central Mediterranean Sea. Deep-Sea Research Part I, 53(1), pp. 62-75, 2006.

[18] Rocchetti, L., Beolchini, F., Ciani, M. \& Dell'Anno, A., Improvement of bioremediation performance for the degradation of petroleum hydrocarbons in contaminated sediments. Applied and Environmental Soil Science, 2, pp. 1-8, 2011.

[19] Liu, C. \& Shao, Z., Alcanivorax dieselolei sp. nov., a novel alkane-degrading bacterium isolated from sea water and deep-sea sediment. International Journal of Systematic and Evolutionary Microbiology, 55, pp. 1181-1186, 2005.

[20] Yakimov, M.M. et al., Oleispira antarctica gen. nov., sp. nov., a new hydrocarbonoclastic marine bacterium, isolated from an Antarctic coastal seawater. International Journal of Systematic and Evolutionary Microbiology, 53(3), pp. 779785, 2003.

[21] Zappalà, G., Caruso, G. \& Crisafi, E., The "SAM" integrated system for coastal monitoring. Environmental Studies, 8, pp. 341-350, 2002.

[22] Zappalà, G., Caruso, G. \& Crisafi, E., Coastal pollution monitoring by an automatic multisampler coupled with a fluorescent antibody assay. Environmental Studies, 10, pp. 125-133, 2004.

[23] Caruso, G. et al., Microbial assemblages for environmental quality assessment: Knowledge, gaps and usefulness in the European Marine Strategy Framework Directive. Critical Reviews in Microbiology, 42(6), pp. 883-904, 2016. 
[24] Kimes, N.E., Callaghan, A.V., Suflita, J.M. \& Morris, P.J., Microbial transformation of the Deepwater Horizon oil spill: Past, present, and future perspectives. Frontiers in Microbiology, 5, p. 603, 2014.

[25] Morris, L., O'Brien, A., Natera, S.H.A., Lutz, A., Roessner, U. \& Long, S.M., Structural and functional measures of marine microbial communities: An experiment to assess implications for oil spill management. Marine Pollution Bulletin, 131, pp. 525-529, 2018.

[26] Delgado-Baquerizo, M. et al., Lack of functional redundancy in the relationship between microbial diversity and ecosystem functioning. Journal of Ecology, 104(4), pp. 936-946, 2016.

[27] Prosser, J.I. et al., The role of ecological theory in microbial ecology. Nature Reviews Microbiology, 5, pp. 384-392, 2007.

[28] Ortmann, A.C., Anders, J., Shelton, N., Gong, L., Moss. A.G. \& Condon, R.H., Dispersed oil disrupts microbial pathways in pelagic food webs. PLoS One, 7(7), pp. $1-9,2012$.

[29] Lee, H. et al., Importance of functional diversity in assessing the recovery of the microbial community after the Hebei Spirit oil spill in Korea. Environment International, 128, pp. 89-94, 2019.

[30] Ziervogel, K., Joye, S.B. \& Arnosti, C., Microbial enzymatic activity and secondary production in sediments affected by the sedimentation pulse following the Deepwater Horizon oil spill. Deep Sea Research II, 129, pp. 241-248, 2016.

[31] Ziervogel, K. et al., Microbial activities and dissolved organic matter dynamics in oilcontaminated surface seawater from the Deepwater Horizon oil spill site. PLoS One, 7(4), e34816, 2012.

[32] Zoppini, A. et al., Bacterial diversity and microbial functional responses to organic matter composition and persistent organic pollutants in deltaic lagoon sediments. Estuarine, Coastal and Shelf Science, 233, 106508, 2020.

[33] Kamalanathan, M. et al., Extracellular enzyme activity profile in a chemically enhanced water accommodated fraction of surrogate oil: Toward understanding microbial activities after the Deepwater Horizon oil spill. Frontiers in Microbiology, 9, 798, 2018. 